Dept. of Pathology,

Animal Reproduction Research Institute (A.R.R.I.)

\title{
TOXOPATHOLOGICAL STUDIES ON THE EFFECT OF FLUORIDE POLLUTION ON MALE AND FEMALE FERTILITY IN ADULT RABBITS
}

(With 18 Figures)

\author{
By \\ HANAA A. EL-HALLAWANY and \\ ABEER E. EL-METWALLY
}

(Received at 15/3/2011)

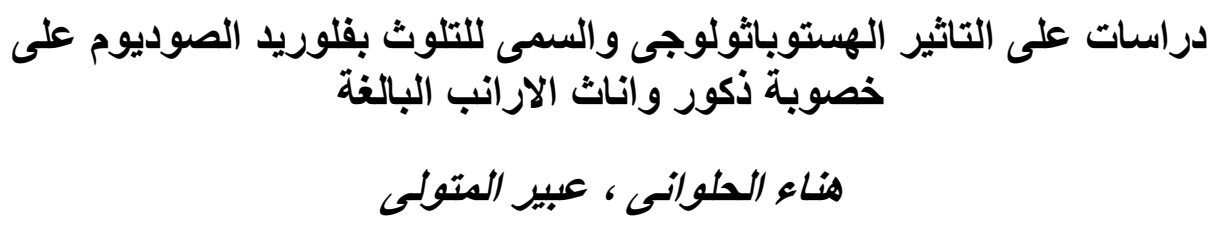

استخدمت أربعة و عشرون ( 15 الذكور و الإناث 9 9) من الأر انب البيضاء لدر اسة تأثثر فلوريد

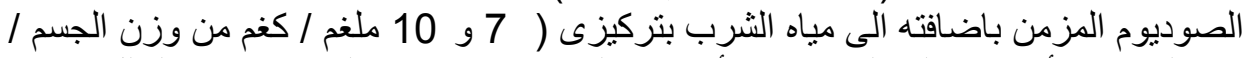

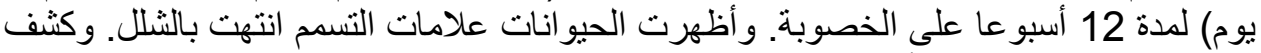

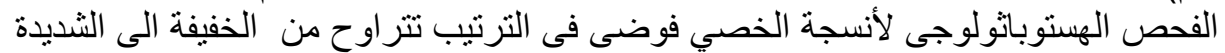

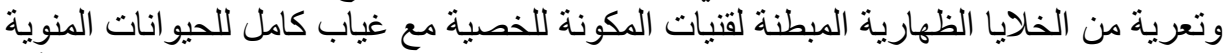

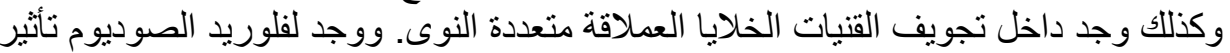

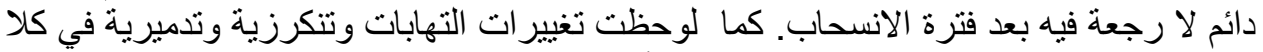

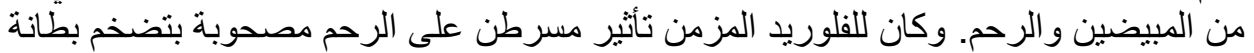

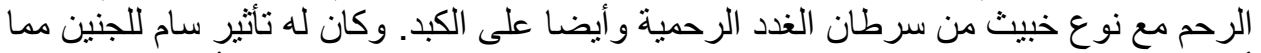

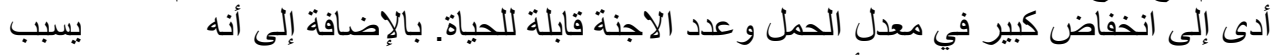

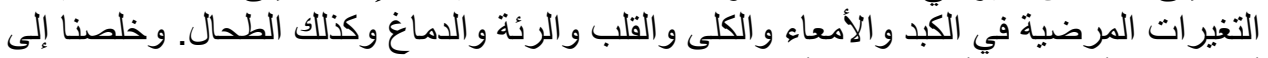
أن درجة الأضر ار بالأنسجة في الأنسجة المختلفة يتناسب طرديا مع الجر الجر عة من الفلور ايد.

\section{SUMMARY}

Twenty four (15 male and 9 female) albino rabbits were used for studying the effect of chronic sodium fluoride $(\mathrm{NaF})$ administration in drinking water ( 7 and $10 \mathrm{mg} / \mathrm{kg}$ body wt/day) for 12 weeks on fertility. Animals showed signs of intoxication and finally paralysis. Histopathological examination of testis revealed mild to severe disorganization and denudation of germinal epithelial cells with complete absence of sperms and reduction of spermatogenesis as well as intraluminal multinucleated spermatides. $\mathrm{NaF}$ has permanent and irreversible effect after the 
withdrawal period. Inflammatory and degenerative changes were observed in both ovaries and uteri. Chronic fluorosis had carcinogenic effect on uterus as endometrial hyperplasia with solid type of clear cell adenocarcinoma and also on liver. It had a fetotoxic effect resulting in a significant reduction in pregnancy rate and the number of viable feoti in treated groups. In addition to, it induced pathological changes in liver, intestine, kidney, lung, heart and brain as well as spleen. We concluded that the degree of histopathological damages of different tissues seemed to be directly proportional to the dosage of fluoride.

Key words: Sodium fluoride, histopathology, fertility, rabbits, reproductive organs, toxicity, internal organs.

\section{INTRODUCTION}

Water pollution has become worldwide phenomenon. The underground water is polluted by many hazard pollutants like fluoride $(\mathrm{F})$, heavy metals and pesticides. Fluoride is one of the major concerns among these pollutants and is widely present in the environment: in water, soil and air as well as produced from industrial sources and may cause chronic fluorosis in grazing animals. It is an essential ion for health of human being (Loganathan et al., 2001; Sharma et al., 2004; Zhang et al., 2006). But excessive $\mathrm{F}$ intake for a prolonged period can induce chronic fluorosis which adversely affects the health of humans and animals with great economic loss in animal production (Kumar et al., 2010). Earlier studies indicated that the incidence and severity of chronic $\mathrm{F}$ intoxication are greatly influenced by socio-economic, climatic, and nutritional status (Zhou et al., 2007).

The main pathway of $\mathrm{F}$ exposure is the ingestion of water from contaminated water sources (Mona and Mai, 2006; Zhou et al., 2009). Fluoride is rapidly absorbed through gastrointestinal tract and lungs at the rate of $95 \%$. Then, it rapidly distributed into the intracellular and extracellular fluids of tissues by systemic circulation. More than $90 \%$ of the total body burden is retained in the bones and teeth (Inkielewicz and Krechniak, 2003; Ersan et al., 2010).

According to World Health Organization (1984), permissible limit of $\mathrm{F}$ in drinking water is $1.5 \mathrm{ppm}$. Egypt is one of about 21 developing nations that have problems with endemic fluorosis. $\mathrm{F}$ concentration in industrial waste water samples collected from Abu Zabaal and Ahlia areas around Cairo vary from $1.13-7.10 \mathrm{mg} / \mathrm{L}$ (Abdel-Halim et al., 2003). 
The effect of fluoride on male and female fertility has become an area of growing concern. Various studies show that fluoride causes adverse effects on male and female fertility (Wan et al., 2006; Darmani et al., 2001).

Earlier works revealed that Sodium fluoride $(\mathrm{NaF})$ accumulates not only in bones and teeth but also in soft tissues and causing pathological changes in different internal organs with disturbance in their functions as liver, intestine, kidney, lung, heart and brain as well as spleen (Shashi and Thapur, 2001; Machalinska et al., 2002; Shashi, 2002; Dina et al., 2006; Zhou, 2007; Ersan et al., 2010; Heba et al., 2010; Kumar et al., 2010).

The National Research Council Report (NRC) (2006) indicated that high $\mathrm{F}$ concentrations have a marked effect on human fertility and development as $\mathrm{F}$ can penetrate the placental barrier (Zakrzewska et al., 2002). So it has a great risk of miscarriages and pregnancy complications with infant mortality and increase Down's syndrome as well as it may be a carcinogic.

The objective of this study, is to clarify the outcome of high $\mathrm{NaF}$ exposure on male and female reproductive system and internal organs histopathology furthermore, the effect of stopping administration of $\mathrm{NaF}$ on male rabbit testis was investigated

\section{MATERIALS and METHODS}

Twenty four ( 15 male \& 9 female) albino rabbits with body weights range of $1200-1250 \mathrm{~g}$ were used for this study. All animals were acclimatized for one week before being dosed. They were exposed to a natural light-dark cycle. Food was supplied in the form of standard rabbit chow (pellets) and natural tap water was provided ad libitum. The rabbits were housed in a well-ventilated animal houses and each group was caged separately, at a temperature of $29-32^{\circ} \mathrm{C}$ under proper hygienic conditions (Kumar et al., 2010).

I- Preparation of dosages of sodium fluoride: Crystalline powder Natrium Fluoride (Sigma, Germany) was dissolved in tap water. It administrated at a concentration of $7 \mathrm{mg} \mathrm{NaF} / \mathrm{kg}$ b.w. (group II \& IV) and $10 \mathrm{mg} \mathrm{NaF} / \mathrm{kg}$ b.w. (group III \& V) (Abdel-Halim et al., 2003; Mona and Mai, 2006).

II- Experiments performed: The following experiments were carried out on 24 rabbits which were divided into five groups:

1- The animals of group I ( 3 male \& 3 female), serving as the control, received tap water for 12 weeks. 
2- The animals of group II ( 3 male $\& 3$ female), received tap water with $7 \mathrm{mg} / \mathrm{L} \mathrm{NaF} / \mathrm{kg}$ b.w. for 12 weeks then sacrificed.

3- The animals of group III ( 3 male $\& 3$ female), received tap water with $10 \mathrm{mg} / \mathrm{L} \mathrm{NaF} / \mathrm{kg}$ b.w. for 12 weeks then sacrificed.

4- The animals of group IV (3 male), received tap water with $7 \mathrm{mg} / \mathrm{L}$ $\mathrm{NaF} / \mathrm{kg}$ b.w. for 8 weeks. On day $60, \mathrm{NaF}$ was withdrawn and tap water alone was administered to animals for 4 weeks then sacrificed.

5- The animals of group V (3 male), received tap water with $10 \mathrm{mg} / \mathrm{L}$ $\mathrm{NaF} / \mathrm{kg}$ b.w. for 8 weeks. On day $60, \mathrm{NaF}$ was withdrawn and tap water alone was administered to animals for 4 weeks then sacrificed.

III- Histopathological examination: After completion of the experiments, the animals were sacrificed and sutable samples from male and female reproductive organs and liver, intestine, kidney, heart, lung and brain were routinely processed, embedded in paraffin wax. They were serially sectioned at 3-5 $\mu \mathrm{m}$ and stained with hematoxylin and eosin then examined under the light microscope (Bancroft and Marilyn, 2002).

\section{RESULTS and DISCUSSION}

\section{Clinical signs:}

In this study, effects of long-term exposure of adult rabbit to $\mathrm{NaF}$ administered in drinking water on the integral indices of the animals were studied. Animals showed signs of intoxication: nervous manifestation included muscle tremor, weakness, pupilary dilatation and hyperesthesia. After 6 weeks, there were gastrointestinal symptoms including loss of appetite, constipation and intermittent diarrhea. Also, lethargy was observed on the most of treated rabbits. These results agreed with those of Shashi (2002); Tiwari and Pande (2009); Ulemale et al. (2010) who aimed the occurrence of gastroenteritis into the irritation of stomach with the formation of hydrofluoric acid.

At the end of experiment all animals showed various degrees of scaly feet and most of them showed ulcers in their hind feet ended by lacerated skin, appearance of bone and finally paralysis.

\section{Microscopical examinations of tissues:}

Numerous reports indicated that $\mathrm{F}$ in varying concentrations leading to generation of superoxide free radicals which play an important role with lipid peroxidation in fluorosis through it may lead to chemical modification and impairment of proteins, lipids, carbohydrates, and nucleotides in living cells. Also, this toxicity is accompanied by a decline in activities of some antioxidant enzymes, viz., glutathione peroxidase (GSH-PX) as well as 
reducing substances like glutathione and ascorbic acid (Chinoy, 2003; Mona and Mai 2006). On the other hand, Shashi (2003) reported that F inhibits numerous phosphatases, kinases and ATPase which are associated with cell energy processes which negatively affecting the carbohydrates, proteins and lipids metabolism.

\section{1- Male reproductive organs:}

A- Testis: It is known that the normal testicular structure and the maintenance of its internal microenvironment are important for sperm production and for maintaining good quality. So the histopathological changes in the testis are affecting on the process of spermatogenesis (Wan et al., 2006).

In this study, the gross appearance of testicles was prominently atrophied and soft especially in males which treated with $10 \mathrm{mg} \mathrm{NaF}$.

Microscopic examination of the control rabbit testis showed normal histology. Rabbits treated with $10 \mathrm{mg} / \mathrm{L} \mathrm{NaF}$ (group III) showed severe disorganization and denudation of germinal epithelial cells (primary and secondary spermatocytes) of seminiferous tubules with complete absence of sperms in the lumina of most tubules so spermatogenesis was severely reduced. There was necrosis in other spermatogenic cell. Vacuoles formation in the germinal cells was observed. In addition to, numerous multinucleated spermatides were prominently observed in the lumen as well as edematous fluid and suggested testicular degeneration. Leydig cells showed atrophy and sertoli cell decreased. Interstitial blood vessels were severely congested. Thickening of tunica albuginia with edema were observed (Fig: 1a \&b). While in group II (treated with $7 \mathrm{mg} / \mathrm{L} \mathrm{NaF} / \mathrm{kg}$ ) showed the same lesions but in mild to moderate severity (Fig. 2).

These findings support the results from other reports (Wan et al., 2006; Liu et al., 2008; Tiwari and Pande 2009) which indicated that F in various dosages and length of toxic exposure altered testis histology resulting in structural defects. Long et al. (2009) reported that blood-testis barrier protects spermatogenic cells and the process of spermatogenesis through keeping the fluoride concentration lower in the testis than in the plasma. If $\mathrm{F}$ cross this permeable barrier during prolonged exposure, it causes lack of maturation and differentiation of spermatocytes, fragmentation of spermatozoa in the epididymis, and even cessation of spermatogenesis (Susheela and Kumar, 1993; Sarkar et al., 2006). On the other hand, it causes necrosis and sloughing off of the spermatogenic cells in the lumen of seminiferous tubules (Chinoy, 1997). The decline in the number of Leydig cells might diminish the reproductive hormones which affect on fertility (Doull et al., 2006). 
B- Epididymis: The epididymis is the site for maturation of spermatozoa, where they acquire motility and fertilizability (Chinoy et al., 1997). NaF treatment disturbs the function of epididymis (Narayana and Chinoy, 1994), leading to alteration in sperm motility, viability and subsequently their fertility (Chinoy and Sequeira, 1992).

In this work, caput and cauda of epididymis in rabbits treated with $10 \mathrm{mg} / \mathrm{L} \mathrm{NaF}$ (group III) showed marked histological alterations in the epithelial cells of their ductules. In caput, the tubules were deshaped with loss of cilia of the epithelial lining and possessed little or no spermatozoa (Fig. 3). In cauda epididymis, the epithelial cell height was reduced with nuclear pyknosis, denudation of cells, and absence of sperm occurred. While in rabbits treated with $7 \mathrm{mg} / \mathrm{L} \mathrm{NaF}$, mild to moderate alterations were noticed. These changes coincide with Chinoy et al. (1997); Tiwari and Pande (2009) who administrated $20,50 \mathrm{mg} / \mathrm{kg}$ of $\mathrm{NaF}$ in drinking water for 30 days.

In order to study reversibility (group IV \& V) in this work, the effects of $\mathrm{NaF}$ were permanent and irreversible. On the other hand, Chinoy et al. (1997); Zakrzewska et al. (2002) who found that toxic effects of fluoride disappeared after removal of the intoxication source.

\section{2- Female reproductive organs:}

A- Ovary: The macroscopic examinations of the ovary in this work were apparently normal except somewhat congestion.

Histopathologically, the ovary revealed necrosis, atrophy of follicular cells with interstitial edema and congestion. These degenerative changes accompanied by monocyte infiltrations in the interstitial tissue were most pronounced in animals treated with $10 \mathrm{mg} \mathrm{NaF}$.

Similar findings observed by Chinoy and Patel (2001); Jhala et al. (2004). These lesions could be due to a lack of available proteins necessary for cell division, growth, and differentiation of germ cells during oogenesis or else inhibition of the hypothalamus (Yuan et al., 1993) or pituitary by fluoride, and hence a decrease in folliclestimulating hormone (FSH) secretion (Xu et al., 1997).

B- Uterus: The present study showed that the long-term exposure of female rabbits to $\mathrm{NaF}$ at a concentration of 7 and $10 \mathrm{mg} / \mathrm{kg} \mathrm{b.w}$. had reduction in pregnancy rate and there was a significant reduction in the number of viable fetuses in treated groups compared to the control group. Two and one out of females in group II and III respectively give birth after two months from the beginning of the experiment. All the fetai were weak and dead within two days. 
These results were coincide with those obtained by Darmani et al. (2001) in mice and by Al-Hiyasat et al. (2000); Verma and Sherlin (2001) in rat as well as in rabbits by Shashi (1994). The significant reduction in pregnancy rate and the number of viable foeti may be due to the alteration of the reproductive endocrine functions leading to decreased secretion of progesterone which is needed for endometrial alteration at the time of implantation and is necessary for successful pregnancy (Darmani et al., 2001). On the other hand, Patel and Chinoy (1998); Verma and Sherlin (2001) aimed the fetotoxic effect of chronic flourosis to a significant decline in DNA and RNA levels of ovary and uterus which leading to alterations in nucleic acid and protein metabolism in these organs resulting in structural changes .

In the present investigation, the macroscopic examinations of all uteri showed congestion, edema and somewhat haemorrhage. In one case from group II (still non-pregnant till the end of experiment), there were whitish peaded like nodules $0.5 \mathrm{~cm}$ in diameter plugged from the uterine surface which is smaller than that observed by Asakawa et al. (2008).

Histopathologically, the examined uteri revealed no changes in control group. Treated groups with $\mathrm{NaF}$ showed chronic metritis characterized by focal and diffuse subepithelial inflammatory cell infiltrations of lymphocytes and plasma cells. Moreover, there were erosion and desquamation of the uterine epithelium. Uterine glands showed necrosis, periglandular fibrosis and inflammatory infiltrations with cystic dilatation. There were pronounced congestion in blood vessels and other parts revealed edema and haemorrhage (Fig. 4a\&b). Diffuse subserosal mononuclear inflammatory cells infiltrations were observed. The same histopathological changes described by Guney et al. (2007); Kamble and Velhal (2010).

Also, one case in group II ( $7 \mathrm{mg} \mathrm{NaF} / 90$ days) in this study showed endometrial hyperplasia with solid type of clear cell adenocarcinoma in which the neoplastic cells often infiltrated into the deep myometrium as single nest or small nests of neoplastic epithelial cells. These neoplastic epithelial cells were pleomorphic varied from cuboidal to more fusiform in their morphology. Neoplastic cells had rounded to ovoid nuclei and scant eosinophilic cytoplasm. On the other hand; some cells were devoid from nuclei. The nuclear to cytoplasmic ratio was law (Fig. 5 \& 6). Mitotic figures in the adenocarcinoma were significantly less frequent.

Chinoy and Patel (2001) recorded that there were a significant positive correlation was found between fluoride concentration in drinking water and uterine cancer mortality. The observed endometrial hyperplasia 
and adenocarcinomas is similar to that found in previous studies by Asakawa et al. (2008) who referred the presence of endometrial hyperplasia in rabbits may be occur as a result of estrogen stimulation and also observed by Silverberg and Kurman (1992) in women. In addition to, Darmani et al. (2001) suggest a correlation between disturbances of the reproductive endocrine functions, with fluoride toxicity along the hypothalamic-pituitary-ovario-uterine axis.

More over, Tsutsui et al. (1984); Zeiger et al. (1993) reported that fluoride ions are causing in vitro mutagenesis of Syrian hamster embryo cells through chromosomal damage and interfere with enzymes involved with DNA repair in a variety of cell and tissue studies which indicate that $\mathrm{NaF}$ is genotoxic and capable of inducing neoplastic transformation.

3- Liver: It is an organ of vital importance and very active site of metabolism. Earlier studies showed that fluoride can produce abnormalities in the liver including degenerative and inflammatory changes (Shashi and Thapur, 2001) with hepatic hyperplasia (Kapoor et al., 1993).

In the present investigation, the gross examination of the rabbit's liver in the fluoride-treated groups was enlarged with varied alterations in color from congestion to pale coloration according to the administrated dose. In addition to, most of animals in group III (10mg NaF) showed pen headed white foci on their livers.

The liver of control rabbits showed normal histology. The normal lobular pattern of hepatic cords in group II animals (7 $\mathrm{mg} \mathrm{NaF}$ ) was distorted and the spaces normally occupied by hepatic cells appeared empty. Hepatocytes showed ballooning degeneration. Moderate focal areas of necrotic hepatocytes were present. Also, there were proliferation of hepatic cords and Kupffer's cells. The central vein and hepatic sinusoids were dilated. Light hyperemia on the structure of central veins (Fig: 7). Bile duct proliferation and periportal fibrosis was observed. The same histopathological changes observed in group II became more pronounced at higher fluoride concentration. In addition to, moderate leukocytes infiltration was also evident in certain areas. Numerous centrilobular micronecrotic foci were found (Fig: 8 a \& b). Similar changes have been reported in fluoride-treated mice (Ersan et al., 2010), rabbits (Shashi and Thapur, 2001) and in calves (Kapoor et al., 1993). Some hepatic cells in all examined liver were binucleated and they were more pronounced after three months of fluoride administration when massive hepatic cell necrosis occurred (Fig. 9). These binucleated hepatocytes were indicated hepatocellular adenoma and carcinoma under the effect of $\mathrm{NaF}$ treatment 
as previously reported by Bogdanffy et al. (1995); Shashi and Thapur (2001).

4- Intestine: During the present study, the entire small intestine exhibited congestive changes and petechial hemorrhages at different degrees according to the administrated dose.

The microscopic examination of control group revealed normal intestinal appearance. The intestinal histoarchitecture of rabbits showed corrosion of surface mucosa with diffuse punctuate hemorrhages. The submucosa appeared clumped and the muscles layer exhibited hypertrophy. In addition to, the intestine of animals of group III (10 $\mathrm{mg} \mathrm{NaF})$ showed vacuolization and necrosis of cells of folds with loss of surface mucosa. The lumen of glands widened due to disintegration of cells and there marked necrosis. Increased numbers of goblet cells in the villi and in the crypts were observed. Lymphocytic infiltrations were widespread in submucosa and lamina propria (Fig. 10).

More or less similar pathological changes were noticed in the fluoride-treated rabbits by (Sondhi et al., 1995; Shashi, 2002). These damaging effects of fluoride were due to the toxic action of fluoride (Susheela et al., 1992).

5- Kidney: Kidneys are the primary organs concerned with excretion and retention of fluoride so they are the target organs for fluoride toxicity (Inkielewicz, and Krechniaka, 2003). They are among the most sensitive body organs in their histopathological and functional responses to excessive amounts of fluoride (Shashi et al., 2001).

In this work, the gross examination of the kidneys in the fluoridated rabbits appeared slight to moderate enlargement with congestion. The renal histopathological alterations were varied according to the concentration of fluoride but were not seen in any of the control rabbits. Both of group II and III revealed cloudy swelling in cells lining the convoluted tubules with dim appearance. The glomeruli were exhibited hypertrophic. Interstitial nephritis was well marked (Fig: 11). By increasing NaF concentration, cellular necrosis was most pronounced and leading to degeneration of convoluted tubules. The remaining cells showed vacuolization of cytoplasm owing to the cell nuclei were pushed to the basement membranes. The tubular lumen was dilated; nuclei showed disintegration and filled with pertinacious material. Interstitial edema was observed (Fig. 12).

Nearly similar finding were observed by Shashi et al. (2001) in rabbits and Ulemale et al. (2010) in cattle. 
6- Heart: Acute toxic effects of fluoride on the heart are fairly well known but information about the exact nature of these effects as a chronic effect is still very limited (Shashi and Thapur, 2001).

In the present investigation, the gross examination of heart was apparently normal. Histopathologically, the heart sections showed clear differences between controls and experimental animals in both groups. These pathological changes, viz. extensive interstitial edema, small hemorrhages and necrosis were significant in the myocardium. There was clear evidence infiltration of lymphocytes, macrophages and histiocytes. At some places, the cardiac muscle showed extensive vacuole formation as compared to the controls. In the highest dosage group (10 $\mathrm{mg}$ of $\mathrm{NaF}$ ), the myocardial degenerative changes consisting mainly of fragmentation of muscle fibres and dissolution of nuclei with hyperemic vessels were more intensely marked (Fig. 13).

Shashi and Thapar (2001) reported the same histopathological changes in rabbits injected with 5 to $50 \mathrm{mg}$ of $\mathrm{NaF} / \mathrm{kg} \mathrm{b}$. w. /day subcutaneously for 3.5 months. Cicek et al. (2005) suggested that fluoride interferes with myocardial metabolism which leading to appearance of these pathological changes.

7- Lung: It is the main target organ for fluoride-induced toxicity so asthma is the principal respiratory health problem within the aluminum industry due to exposure to inhaled fluoride compounds (O'Donnell, 1995). In this respect, Dina et al. (2006) referred the inflammatory lung injury in response to fluoride occurred due to releasing of high amounts of inflammatory cytokines from epithelial cells which induce endothelial cell barrier dysfunction and leading to significant increase of albumin permeability.

Grossly in this study, lung tissues of group II and III appeared mild to moderate reddish brown in color but normal in size. There were marked histological changes in the lung tissues as loss of alveolar architecture and desquamation of alveolar epithelium. Some emphysematous areas were also observed. There were edema associated with congestion of blood vessels and thickening in their walls. Intraparenchymal mononuclear cell infiltrations mainly as lymphocytes, macrophages and plasma cells were markedly observed. The severity of these pathological lesions increased in animals of group III $(10 \mathrm{mg} \mathrm{NaF})$. In addition to, there were marked alveolar hemorrhage, fibrin deposition and necrosis of alveolar epithelium. Prominent bronchiolitis and ulceration of the bronchiolar epithelium were also seen with desquamation of their epithelial cells (Fig. 14).

Similar changes were observed by Aydin et al. (2003); Oncu et al. (2004); Dina et al. (2006) in rat administrated NaF in drinking water. 
8- Brain: Fluoride is classified as neurotoxic substance and has the ability to cross the blood-brain barrier so the excessive exposure reported to be associated with central nervous system dysfunction (Heba et al., 2010).

Gross examination of the brain tissues in the present work indicated that slightly to moderate congestion in the brain tissues of group II and III.

Histopathologically, the brain sections showed a significant difference between controls and fluoridated rabbits. The main histopathological alterations were congestion of the meningeal, cerebral, cerebellum blood capillaries. Encephalitis was observed in the cortex of cerebrum represented by mononuclear cells aggregations associated with perivascular cuffing appeared only in rabbits exposed to high F dose (Fig. 15). Neurodegenerative changes were detected in nerve cells mainly atrophy and necrosis (Fig. 16) especially in pyramidal cells of hippocampus. Also, nerve cells of cerebral cortex revealed central chromatolysis, edema, atrophy, necrosis and neuronophagia (Fig. 17).

The present results are in accordance with those described by $\mathrm{Ge}$ et al. (2005); Heba et al. (2010) in rats and Shashi (2003) in rabbits. These histological changes mostly pronounced in the hippocampus which explained by Heba et al. (2010) as accumulation of fluoride in neurons leading to degeneration and finally death.

9- Spleen: This organ plays a significant role in hematopoietic system development, particularly during the fetal life and actively provides blood cell production throughout life (Machalinska et al., 2002; Zabulyte et al., 2007) reported that the toxic damage to the spleen caused by the marked negative effects of $\mathrm{F}$ on hematopoiesis.

In this study, NaF caused morphological changes in the spleen ranged from slight to moderate enlargement in its size according to the dose.

Histopathologically, the spleen in control group revealed normal histology. NaF treated rabbits showed activation of white pulp with edema and hemorrhages. Blood vessels revealed congestion with thickening of their walls (Fig. 18a\&b). Our results were inconstant with those of Zabulyte et al. (2007); Zhou et al. (2009) in rat and rabbits. In addition to, red pulp increased and infiltrated by lymphocytes. These changes were more intense in the spleen of rabbits treated with higher doses of F. The same results were coincide to those described by Machalinska et al. (2002) in mice. 

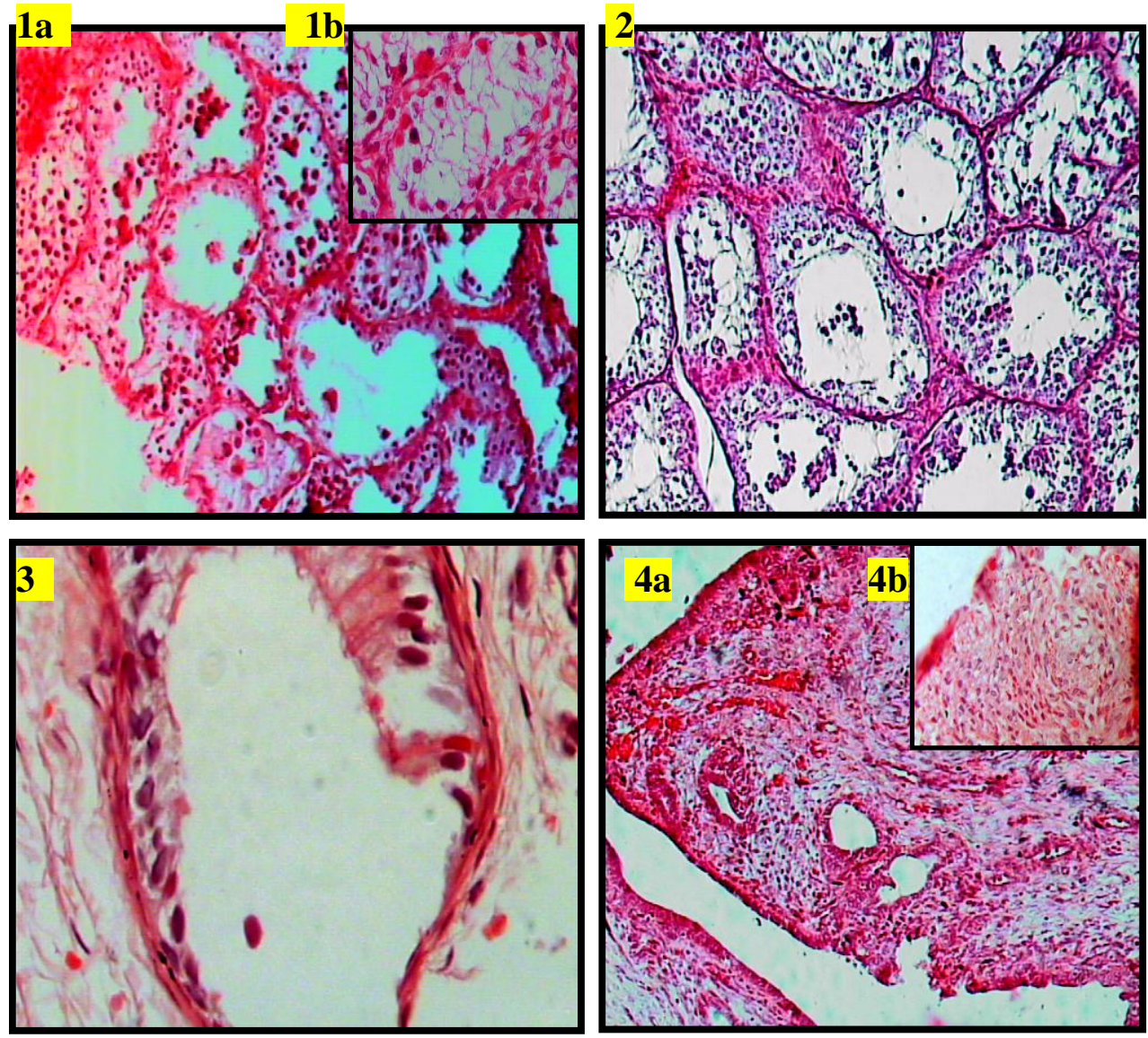

Fig. 1 (a): Rabbit testis treated with $10 \mathrm{mg} / \mathrm{L} \mathrm{NaF}$ showed severe disorganization, denudation of germinal epithelial cells, numerous intraluminal multinucleated spermatides and edematous fluid as well as congested interstitial blood vessels ( H\&E X10). Fig. 1 (b) Rabbit testis treated with $10 \mathrm{mg} / \mathrm{L} \mathrm{NaF}$ showed sloughing off of the spermatogenic cells of seminiferous tubules with complete absence of sperms ( H\&E X40).

Fig. 2: Rabbit testis treated with $7 \mathrm{mg} / \mathrm{L} \mathrm{NaF}$ showed mild to moderate disorganization and denudation of germinal epithelial cells ( H\&E X10).

Fig. 3: Rabbit epididymis treated with $10 \mathrm{mg} / \mathrm{L} \mathrm{NaF}$ showed deshaped tubules with loss of epithelial cilia and possessed no spermatozoa ( H\&E X40).

Fig. 4 (a): Rabbit uterus treated with $10 \mathrm{mg} / \mathrm{L}$ NaF showed chronic metritis characterized by focal and diffuse subepithelial inflammatory cell infiltrations with uterine epithelium erosion as well as edema and haemorrhage. Uterine glands showed cystic dilatation (H\&E X10).

Fig. 4 (b): High power of the previous picture showed necrosis in the uterine glands (H\&E X40). 

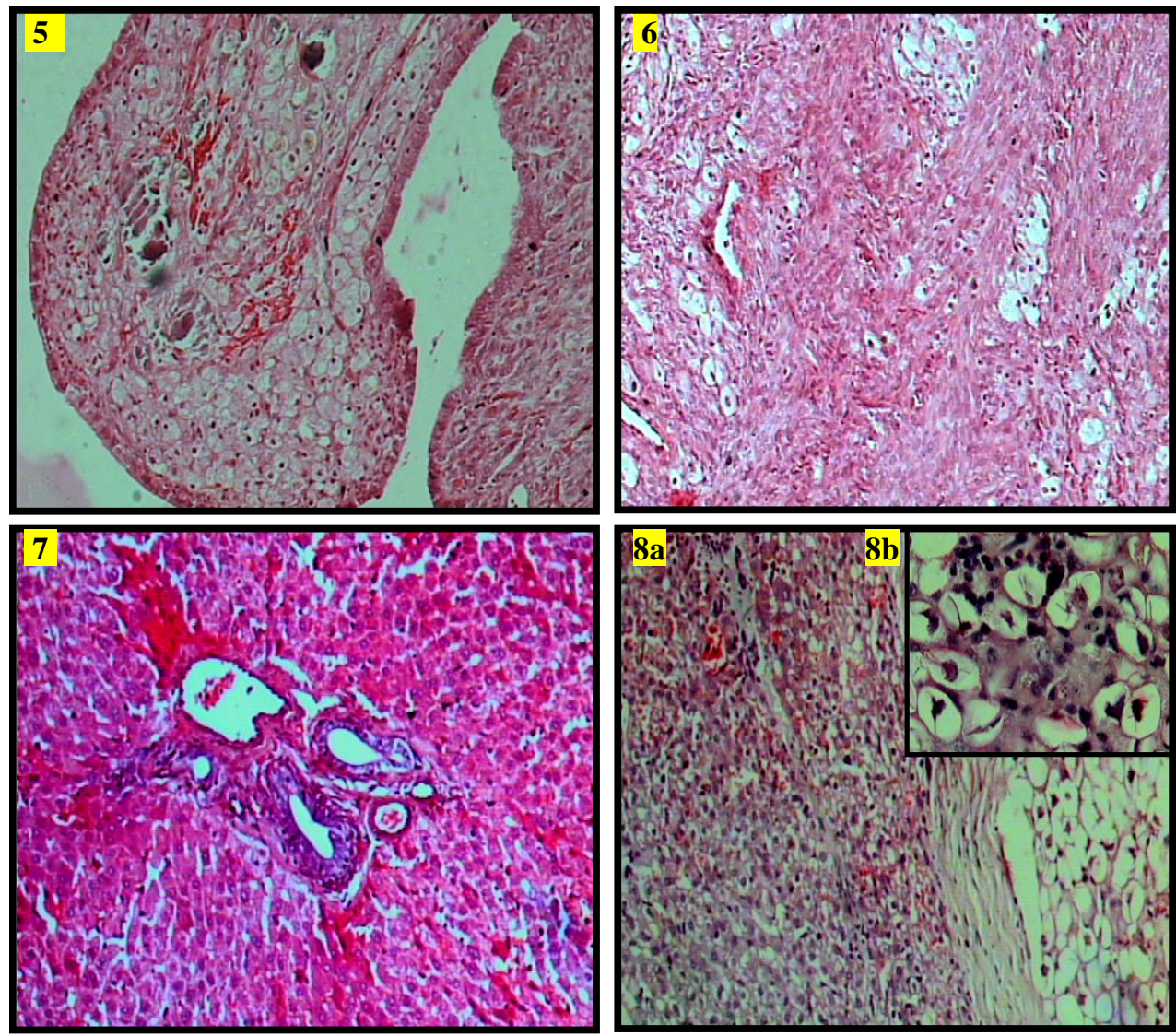

Fig. 5: Rabbit uterus treated with $7 \mathrm{mg} / \mathrm{L} \mathrm{NaF}$ showed endometrial hyperplasia with solid type of clear cell adenocarcinoma which characterized by pleomorphic neoplastic epithelial cells (H\&E X10).

Fig. 6: Rabbit uterus treated with $7 \mathrm{mg} / \mathrm{L} \mathrm{NaF}$ showed invasion of neoplastic cells into the myometrium (H\&E X4).

Fig. 7: Rabbit liver treated with $7 \mathrm{mg} / \mathrm{L} \mathrm{NaF}$ showed hydropic degeneration and necrosis of hepatocytes, proliferation of hepatic cords with dilated and congested central vein and hepatic sinusoids (H\&E X4).

Fig: 8 (a): Rabbit liver treated with 10mg/L NaF showed numerous centrilobular micronecrotic foci and degenerated hepatocytes with dilated, congested hepatic sinusoids (H\&E X4). Fig. 8 (b): rabbit liver treated with $10 \mathrm{mg} / \mathrm{L}$ $\mathrm{NaF}$ showed ballooning degeneration of hepatocytes with moderate leukocytic infiltration (H\&E X40). 

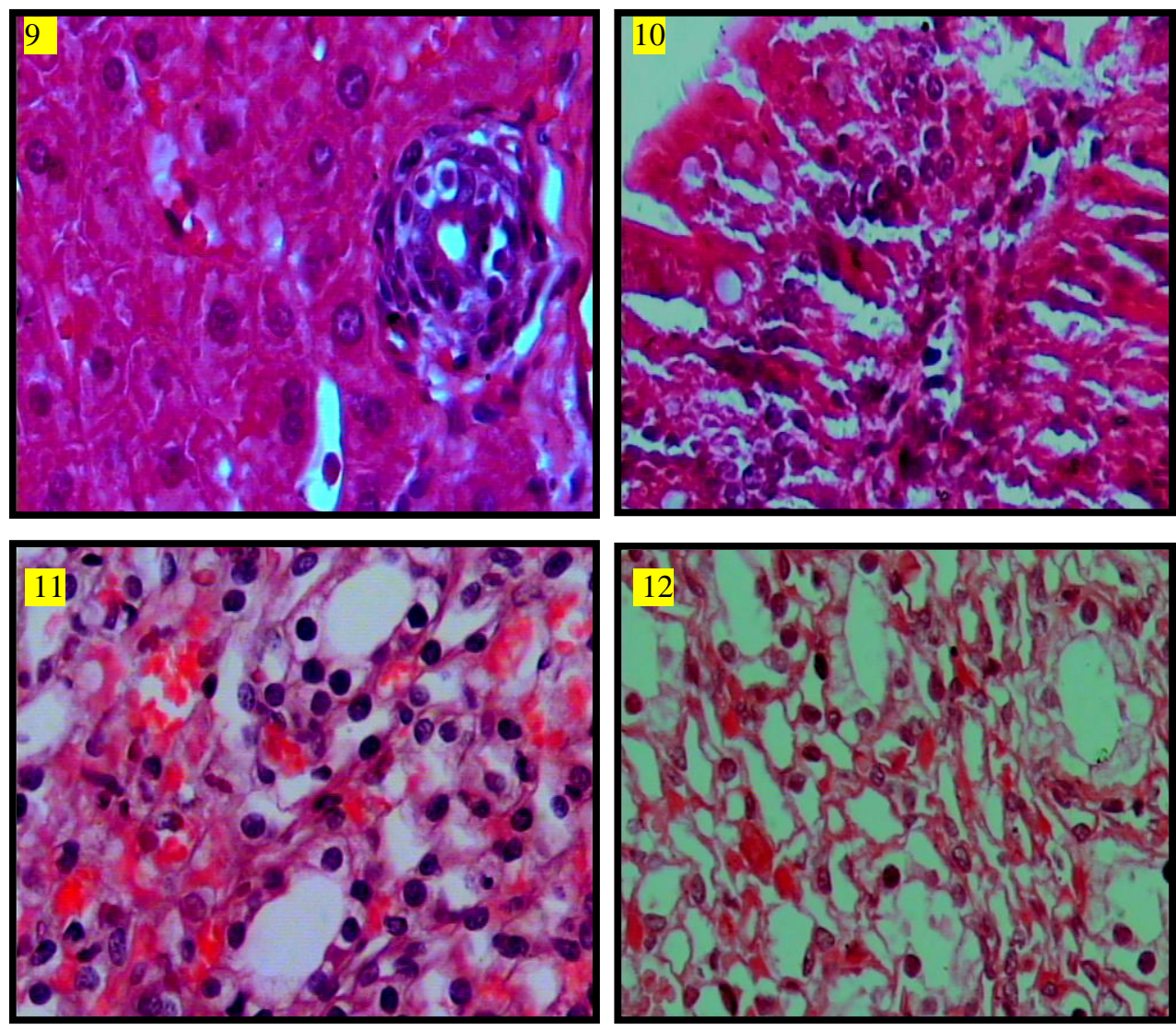

Fig. 9: Rabbit liver treated with $10 \mathrm{mg} / \mathrm{L} \mathrm{NaF}$ showed bile duct proliferation and periportal fibrosis was observed (H\&E X40).

Fig. 10: Rabbit intestine treated with $10 \mathrm{mg} / \mathrm{L} \mathrm{NaF}$ showed vacuolization and necrosis with loss of surface mucosa, increased numbers of goblet cells in the villi and lymphocytic infiltrations in sub-mucosa and lamina propria (H\&E X40).

Fig. 11: Rabbit kidney treated with $7 \mathrm{mg} / \mathrm{L} \mathrm{NaF}$ showed interstitial nephritis with degeneration of convoluted tubules and pronounced congestion(H\&E $\mathrm{X} 40)$.

Fig. 12: Rabbit kidney treated with $10 \mathrm{mg} / \mathrm{L} \mathrm{NaF}$ showed interstitial nephritis with sever degeneration of convoluted tubules and vacuolization of cytoplasm associated with congestion (H\&E X40). 

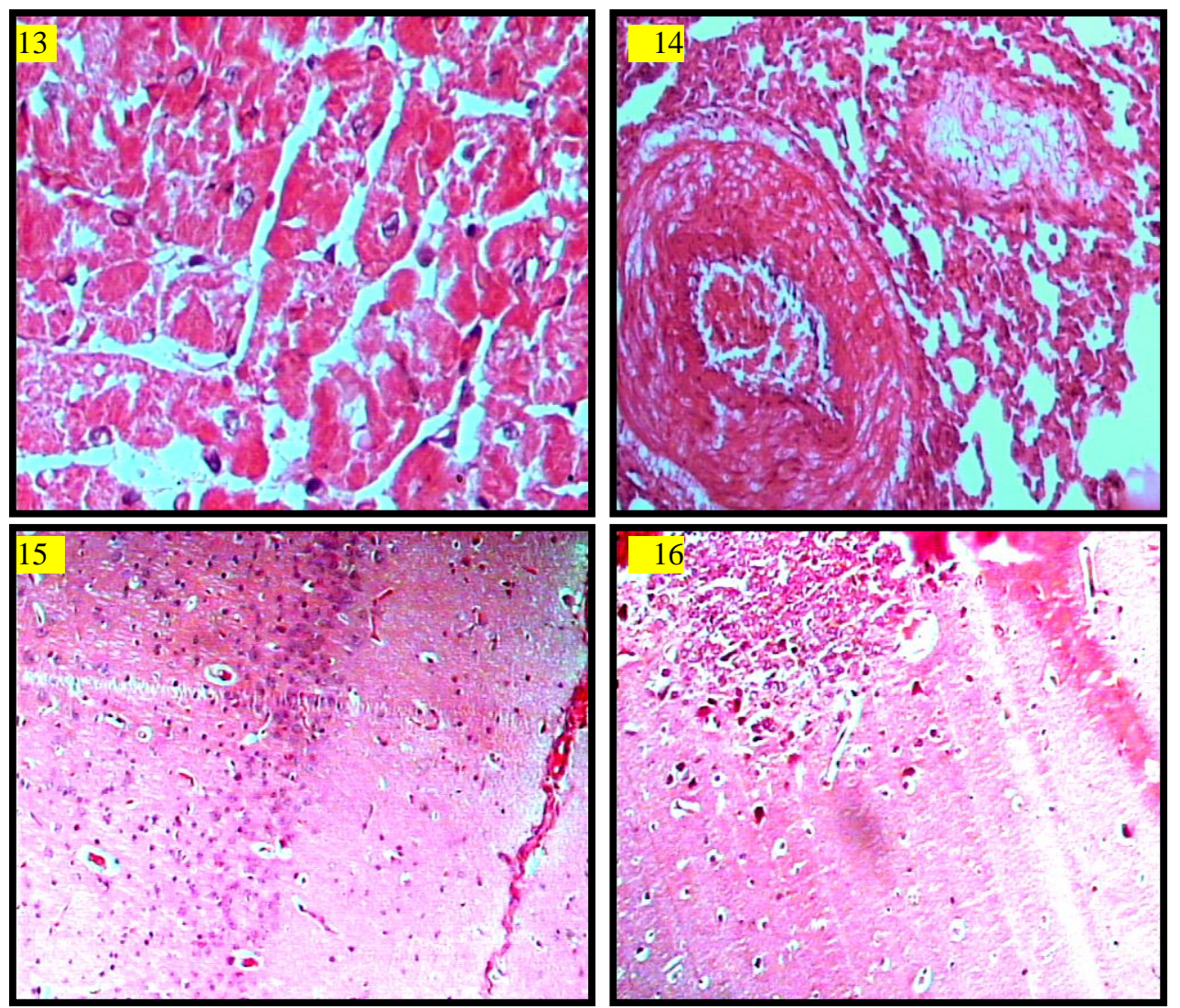

Fig. 13: Rabbit heart treated with $10 \mathrm{mg} / \mathrm{L}$ NaF showed myocardial degenerative changes consisting mainly of fragmentation of muscle fibers and dissolution of nuclei (H\&E X40).

Fig. 14: Rabbit lung treated with $10 \mathrm{mg} / \mathrm{L} \mathrm{NaF}$ showed congestion, thickening of vascular wall associated with emphysema, edema and marked fibrin deposition (H\&E X10).

Fig. 15: Rabbit brain treated with $10 \mathrm{mg} / \mathrm{L} \mathrm{NaF}$ showed vascular congestion, edema and diffuse mononuclear aggregations (H\&E X10).

Fig: 16: Rabbit brain treated with $10 \mathrm{mg} / \mathrm{L} \mathrm{NaF}$ showed focal necrosis with edema and diffuse mononuclear aggregations (H\&E X10). 

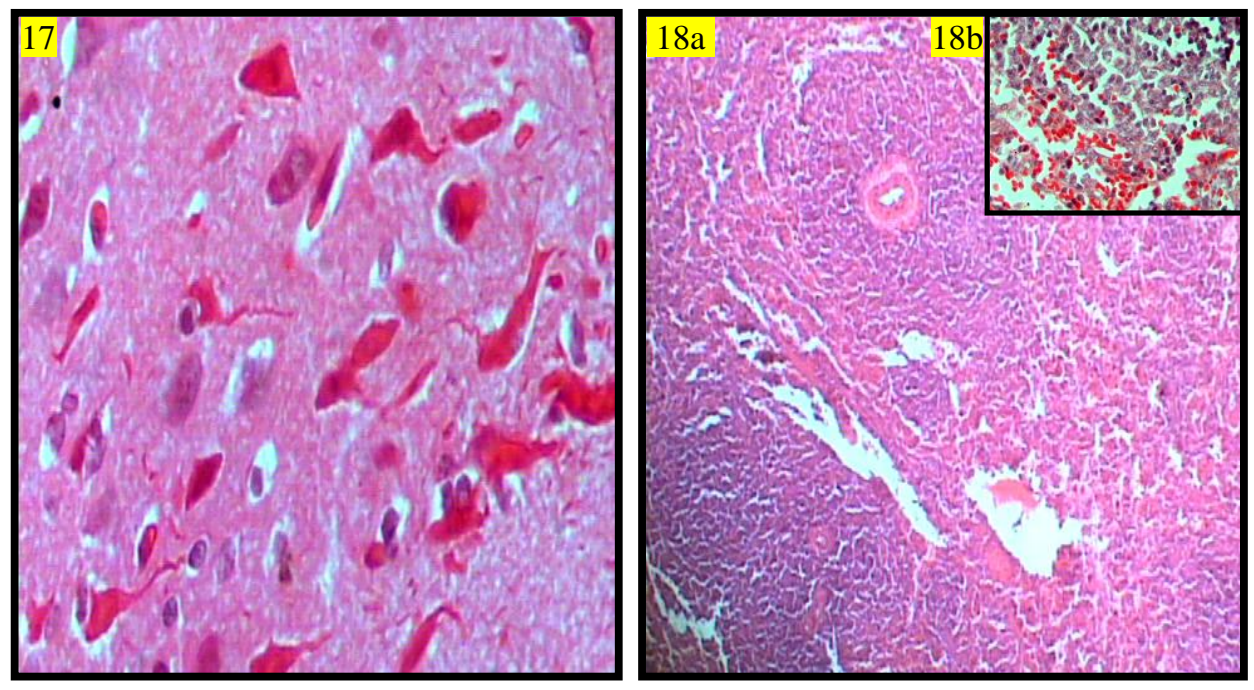

Fig. 17: Rabbit brain treated with $10 \mathrm{mg} / \mathrm{L} \mathrm{NaF}$ showed chromatolysis, edema, atrophy, necrosis and neuronophagia of cells of hippocampus (H\&E X40).

Fig. 18 (a): Rabbit spleen treated with $10 \mathrm{mg} / \mathrm{L} \mathrm{NaF}$ showed activation of white pulp with edema and hemorrhages (H\&E X4). Fig. 18 (b): high power of the previous (H\&E X40).

\section{CONCLUSION}

1- The effects of long-term exposure of adult rabbit to $\mathrm{NaF}$ administered in drinking water showed signs of intoxication as well as ulcers in their hind feet ended paralysis.

2- The degree of morphologically and histopathological damages of different tissues seemed to be directly proportional to the dosage of fluoride.

3- NaF has significant effects on male fertility through histopathological alterations of the reproductive organs accompanied with impairing the process of spermatogenesis. The effects of $\mathrm{NaF}$ are permanent and irreversible after the withdrawal period.

4- The exposure of female rabbits to $\mathrm{NaF}$ had degenerative changes in both ovaries and uteri that affected on the oogenesis with reduction in pregnancy rate. More over $\mathrm{NaF}$ has a fetotoxic effect resulting in significant reduction in the number of viable fetai.

5- The carcinogenic effect of $\mathrm{NaF}$ toxicity were observed in uterus as endometrial hyperplasia with solid type of clear cell adenocarcinoma and also in liver. 


\section{REFERENCES}

Abdel-Halim, S.H.; Shehata, A.M.A. and El-Shahat, M.F. (2003): Removal of zinc and fluoride ions from industrial waste- water plants around Cairo. Bull Environ Contam Toxicol; 70: 262-7.

Al-Hiyasat, A.S.; Elbetieha, A.M. and Darmani, H. (2000): Reproductive toxic effects of ingestion of sodium fluoride in female rats. Fluoride; 33(2): 79-84.

Asakawa, M.G.; Goldschmidt, M.H.; Une, Y. and Nomura, Y. (2008): The immunohistochemical evaluation of estrogen receptor-a and progesterone receptors of normal, hyperplastic, and neoplastic endometrium in 88 pet rabbits. Vet. Pathol; 45: 217-225

Aydin, G.; Cicek, E.; Akdogan, M. and Gokalp, O. (2003): Histopathological and biochemical changes in lung tissues of rats following administration of fluoride over several generations. J. Appl. Toxicol.; 23 (6): 437-446.

Bancroft, J.D. and Marilyn Gamble, (2002): Theory and practice of histological techniques. 5th ed. London Edinburgh New York Philadelphia St. Louis Sydney Toronto.

Bogdanff, M.S.; Makovee, G.T. and Frame, S.R., (1995): Inhalation oncogenicity bioassay in rats and mice with vinyl fluoride. Fundam App. Toxicol; 26: 223-8.

Chinoy, N.J. (2003): Fluoride stress on antioxidant defence systems. Fluoride; 36 (3): 138-141.

Chinoy, N.J. and Patel, T.N. (2001): Effects of sodium fluoride and aluminum chloride on ovary and uterus of mice and their reversal by some antidotes. Fluoride; 34(1): 9-20.

Chinoy, N.J. and Sequeira, E. (1992): Reversible fluoride induced fertility impairment in male mice. Fluoride; 25 (2): 71-76.

Chinoy, N.J.; Sukla, S.; Walimbe, A.S. and Bhattacharya, S. (1997): Fluoride toxicity on rat testis and cauda epididymal tissue components and its reversal. Fluoride; 30: 41-50.

Cicek, E.; Aydin, G.; Akdogan, M. and Okutan, H. (2005): Effects of chronic ingestion of sodium fluoride on myocardium in a second generation of rats. Hum. Exp. Toxicol., 24 (2): 79-87.

Darmani, H.; Al-Hiyasat, A.S. and Elbetieha, A.M. (2001): Effects of sodium fluoride in drinking water on fertility in female mice. Fluoride; 34(4): 242-9.

Dina S. El-Agamy; Nasra H. El-Labban and El-Kashef, H.A. (2006): Effect of fluoride on the respiratory system of rats. J. Basic and Applied Science, 2, 1. 
Doull, J.; Boekelheide, K.; Farishian, B.G.; Isaacson, R.L.; Klotz, J.B.; Kumar, J.V.; Limeback, H.; Poole, C.; Puzas, J.E.; Reed, R.; Thiessen, K.M. and Webster, T.F. (2006): Fluoride in drinking water: a scientific review of EPA's standards [book on the Internet, the print version is forthcoming]. Washington, DC: The National Academies Press; p.164, 171.

Ersan, Y.; Ko, Evren; ARI, $\dot{I}$. and Karademir, B. (2010): Histopathological effects of chronic fluorosis on the liver of mice (Swiss albino). Turk J. Med. Sci.; 40 (4): 619-622.

Ge, Y.M.; Ning, H.M.; Wang, H.W. and Wang, J.D. (2005): Effects of high fluoride and low iodine on brain histopathology in offspring rats. Fluoride; 38(2): 127-132.

Guney, M.; Oral, B.; Demirin, H.; Karahan, N.; Mungan, T. and Delibas, $N$. (2007): Protective effects of vitamins C and E against endometrial damage and oxidative stress in fluoride intoxication. Clin. Exp. Pharmacol. Physiol., 34(5-6): 467-74.

Heba, S. El-lethey; Mervet, M. Kamel and Iman, B. Shaheed, (2010): Neurobehavioral toxicity produced by sodium fluoride in drinking water of laboratory rats. Journal of American Science; 6(5): 54-63.

Inkielewicz, I. and Krechniak, J. (2003): Fluoride content in soft tissues and urine of rats exposed to sodium fluoride in drinking water. Fluoride; 36: 263-266.

Jhala, D.D.; Nair, S.B. and Chinoy, N.J. (2004): Reversible toxicity of fluoride and arsenic in ovary of mice. Fluoride; 37 (2): 71-79.

Kamble, N.A. and Velhal, V.V. (2010): Cytopathological assessment of uterine cells in rattus norvegicus due to induced sodium fluoride. The Second International Conference of National Environmentalists Association; 5 (1): 301-303.

Kapoor, V.; Prasad, T. and Bhatia, K.C. (1993): Effect of dietary fluorine on histopathological changes in calves. Fluoride; 26(2):105-10.

Kumar, N.; Sood, S.; Singh, M.; Makkar, B.; Rohtak, S.S. and Haryana, (2010): Effects of sodium fluoride on the electrocardiogram of male rabbits. Fluoride; 43(2): 124-127.

Liu, H.; Niu, R.; Wang, J.; He, Y. and Wang, J. (2008): Changes caused by and $\mathrm{Pb}$ in energy metabolic enzyme activities in the reproductive system of male offspring rats. Fluoride; 41(3): 184-191.

Loganathan, P.; Hedly, M.J.; Wallace, G.C. and Roberts, A.H. (2001): Accumulation in pasture forages and soils following long term application of phosphorous fertilizers. Eviron. Pollut.; 115(2): 275-282. 
Long, H.; Jin, Y.; Lin, M.; Sun, Y.; Zhanga, L. and Clinch, C. (2009) Fluoride toxicity in the male reproductive system. Fluoride; 42(4): 260-276.

Machalinska, A.; Wiszniewska, B.; Tarasiuk, J. and Machalinskia, B. (2002): Morphological effects of sodium fluoride on hematopoietic organs in mice. Fluoride; 35 (4): 231-238.

Mona, Helal and Mai, El Dakdoky, (2006): Fetotoxicity of fluoride in rats and the protective action of some antioxidants. Fluoride; 39(3): 202-210.

Narayana, M.V. and Chinoy, N.J. (1994): Reversible effect of sodium fluoride ingestion on spermatozoa of the rat. International Journal of Fertility; 39 (6): 337-346.

National Research Council (NRC) (2006): Committee on Fluoride in Drinking Water: A Scientific Review of the EPA's Standards. National Academies Press. Washington DC.

O'Donnell, T.V. (1995): Asthma and respiratory problems - a review. Sci. Total Environ. 163(1-3): 137-145.

Oncu, M.; Gülle, K.; Karaoz, E.; Gultekin, F.; Karaoz, S. and Karakoyun, I. (2004): Biochemical and histopathological effects of chronic fluorosis on lung tissues of first generation rats. Biotechnol. \& Biotechnol. Eq. 18/2.

Patel, D. and Chinoy, N.J. (1998): Ameliorative role of amino acids on fluoride-induced alterations in mice (Part II): ovarian and uterine nucleic acid metabolism Fluoride 31(3): 143-148

Sarkar, S.D.; Maiti, R. and Ghosh, D. (2006): Management of fluoride induced testicular disorders by calcium and vitamin-E coadministration in the albino rat. Reprod. Toxicol; 22(4): 606-12.

Sharma, J.D.; Sharma, M.K. and Agrawal, P. (2004): Effect of Fluoride Contaminated Drinking Water in Albino Rats Rattus norvegicus. Asian J. Exp. Sci.; 18, (1\&2): 37-46.

Shashi, A. (1994): Preliminary observations on alterations in rabbit ovary DNA and RNA content in experimental fluorosis. Fluoride; 27(2): 76-80.

Shashi, A. (2002): Histopathological effects of sodium Fluoride on the duodenum of rabbits. Fluoride; 35 (1): 28-37.

Shashi, A. (2003): In vivo studies concerning toxic effects of sodium fluoride on hepatic function in rabbits. Fluoride; 36(1): 30-7.

Shashi, A. (2003): Histopathological investigation of fluoride induced neurotoxicity in rabbits. Fluoride; 36(2): 95-105. 
Shashi, A. and Thapur, S.P. (2001): Histopathology of myocardial damage in experimental fluorosis in rabbits. Fluoride; 34: 43-50.

Shashi, A. and Thapur, S.P. (2001): Histopathology of fluoride-induced hepatotoxicity in rabbits. Fluoride, 34(1): 34-42.

Shashi, A.; Singh, J.P. and Thapur, S.P. (2001): Toxic effects of fluoride on rabbit kidney. Fluoride; 35 (1): 38-50.

Silverberg, S.G. and Kurman, R.J. (1992): Tumors of the uterine corpus and gestational trophoblastic disease. In: Atlas of Tumor Pathology, 3rd series, fascicle 3, pp. 15-89. American Registry of Pathology, Washington, DC. Fluoride Vol. 34 No. 4 242-249 2001 Research Report.

Sondhi, H.; Gupta, M.L. and Gupta, G.L. (1995): Intestinal effects of sodium fluoride in Swiss albino mice. Fluoride; 28 (1): 21-4.

Susheela, A.K.; Das, T.K.; Gupta, I.P.; Tandon, R.K.; Kacker, S.K.; Ghosh, P. and Deka, R.C. (1992): Fluoride ingestion and its correlation with gastrointestinal discomfort. Fluoride; 25 (1): 5-22.

Susheela, A.K. and Kumar, A.A. (1993): Study of the effect of high concentrations of fluoride on the reproductive organs of male rabbits, using light and scanning electron microscopy. Fluoride; 26 (2): 148.

Tiwari, S. and Pande, R.K. (2009): Effect of fluoride on the hematological parameters and reproductive organs of male albino rat. $J$. Ecophysiol. Occup. Hlth; 9: 119-129.

Tsutsui, T.; Suzuki, N. and Ohmori, M. (1984): Sodium fluoride-induced morphological and neoplastic transformation, chromosome aberrations, sister chromatid exchanges, and unscheduled DNA synthesis in cultured syrian hamster embryo cells. Cancer Res. Mar; 44(3): 938-41.

Ulemale, A.H.; Kulkarni, M.D.; Yadav, G.B.; Samant, S.R.; Komatwar, S.J. and Khanvilkar, A.V. (2010): Fluorosis in Cattle Veterinary World; 3 (11): 526-527.

Verma, R.J. and Sherlin, D.M. (2001): Vitamin C ameliorates fluorideinduced embryotoxicity in pregnant rats. Hum. Exp. Toxicol. Dec; 20 (12): 619-23.

Wan, S.X.; Zhang, J.H. and Wang, J.D. (2006): Effects of high fluoride on sperm quality and testicular histology in male rats. Fluoride; 39(1): 17-21.

World Health Organization (WHO) (1984): Environmental Guidelines by WHO for drinking water quality: 1-3, Geneva. 
Xu, Y.; Yuan, S. and Xie, Q. (1997): Effects of fluorosis on induced secretion of rat prolactin in vivo and in vitro. Fluoride; 30(3): 173-178.

Yuan, S.D.; Xie, Q.W. and Lu, F.Y. (1993): Changes of serotonin content and turnover rate in hypothalamus of female rat during fluorosis. Fluoride; 26 (1): 57-60.

Zabulyte, D.; Uleckiene, S.; Kalibatas, J.; Paltanaviciene, A.; Jascaniniene, N. and Stosik, M. (2007): Experimental studies on effect of sodium fluoride and nitrate on biochemical parameters in rats. Bull Vet. Inst. Pulawy, 51: 79-82.

Zakrzewska, H.; Udała, J. and Błaszczyk, B. (2002): In vitro influence of sodium fluoride on ram semen quality and enzyme activities. Fluoride; 35 (3): 153-160.

Zeiger, E.; Shelby, MD. and Witt, KL. (1993): Genetic Toxicity of Fluoride, Environmental and Molecular Mutagenesis, 21:4, 309-318 (Experimental Carcinogenesis and Mutagenesis Branch, National Institute of Environmental Health Sciences).

Zhang, J.H.; Liang, C.; Ma, J.; Niu, R.Y. and Wang, J. (2006): Effects of sodium fluoride and sulfur dioxide on sperm motility and serum testosterone in male rats. Fluoride; 39(2): 126-31.

Zhou, B.; Wang, H.; Wang, J.; Zhang, J.; Yan, X. and Wang, J. (2007): Effects of malnutrition and supplemented nutrition on nonspecific immune function changes induced by fluoride in rabbits. Fluoride; 40(3): 169-177.

Zhou, B.; Wang, H.; Wang, J.; Zhang, J.; Yan, X. and Wang, J. (2009): Effects of malnutrition and supplemented nutrition on specific immune parameter changes induced by fluoride in rabbits. Fluoride; 42 (3): 216-223. 